\title{
Agronomic Factors Associated with Bacterial Leaf Streak Development Caused by Xanthomonas vasicola pv. vasculorum in Corn
}

\author{
T. Hartman, ${ }^{1,2}$ J. Harbour, ${ }^{1,3}$ B. Tharnish, ${ }^{1}$ J. Van Meter, ${ }^{4}$ and T. A. Jackson-Ziems ${ }^{1, \dagger}$ \\ ${ }^{1}$ University of Nebraska-Lincoln, Lincoln, NE 68583 \\ ${ }^{2}$ Bayer CropScience, Sabin, MN 56580 \\ 3 JTK Agriculture, LLC, Lincoln, NE 68504 \\ ${ }^{4}$ Nebraska Department of Agriculture, Lincoln, NE 68509 \\ Accepted for publication 6 April 2020.
}

\begin{abstract}
In 2016, the bacterium Xanthomonas vasicola pv. vasculorum was reported causing bacterial leaf streak on Nebraska corn. Prior to this report, the pathogen was reported on corn only in South Africa. Hence, there was a lack of information about the effects of corn production practices on bacterial leaf streak development. A survey of growers, crop consultants, extension agents, and others in the field of agriculture was initiated during the 2016 and 2017 corn growing seasons to examine agronomic factors that may affect the disease. Survey respondents were asked to submit a symptomatic leaf sample for pathogen confirmation via polymerase chain reaction, along with a completed survey on corn production practices. Analyses of 325 survey responses via random forest
\end{abstract}

ABSTRACT

The United States is the largest producer of corn (Zea mays L.) in the world, and the top five corn producing states by volume are Iowa, Illinois, Nebraska, Minnesota, and Indiana, respectively. At 323.7 million $\mathrm{m}^{3}$ produced in 2016, these states produced $60.6 \%$ of the corn crop in the United States (USDA-NASS 2016). Diseases can often limit corn production. Xanthomonas vasicola pv. vasculorum, causal agent of bacterial leaf streak in corn, was reported for the first time in the United States (Korus et al. 2017) in Nebraska in 2016. The only previous report of this pathogen causing disease on corn was in South Africa (Dyer 1949). Since its initial confirmation in Nebraska, $X$. vasicola pv. vasculorum was quickly confirmed in eight additional states, including four of the top five corn producing states: Colorado, Iowa, Illinois, Kansas, Minnesota, Oklahoma, South Dakota, and Texas (Bowman and Bissonnette 2016; Korus et al. 2017). Since its confirmation in the United States, $X$. vasicola pv. vasculorum was also reported causing bacterial leaf streak on corn in Argentina (Plazas et al. 2018) and Brazil (Leite et al. 2018).

Symptoms of infection by $X$. vasicola pv. vasculorum in corn usually include yellow or tan-to-dark brown interveinal spots or streaks on the leaves. These symptoms are typically first observed on lower leaves, although this is not always the case. The bacterium also causes gumming disease of sugarcane in production areas around most of the world and symptoms include leaf blight and systemic vascular wilt (North 1935). X. vasicola pv. vasculorum has

${ }^{\dagger}$ Corresponding author: T. A. Jackson-Ziems; tjackson3@unl.edu

Funding: Support was provided by Nebraska Corn Board (88-R-1516-05).

*The $e$-Xtra logo stands for "electronic extra" and indicates supplementary materials are published online.

The author(s) declare no conflict of interest.

(C) 2020 The American Phytopathological Society analysis indicated that irrigation, planting date, and crop rotation were the three most important predictors of corn samples testing positive for $X$. vasicola pv. vasculorum. According to a classification and regression tree analysis, irrigation use, the V7-R2 range of crop stages, multiple years of corn in a crop rotation or a corn-sorghum rotation, and planting dates after 2 May, were most closely associated with corn samples testing positive for $X$. vasicola pv. vasculorum. $\chi^{2}$ tests of independence indicated that applications of nitrogen fertilizer and glyphosate herbicide use may also be related to bacterial leaf streak development.

Keywords: bacteriology, ecology and epidemiology not been reported in sugarcane in the United States nor has the vascular wilt phase been reported in corn.

There has been some research into the epidemiology of this pathogen in other areas (Karamura et al. 2015; Korus et al. 2017; Lang et al. 2017; North 1935; Ricaud and Autrey 1989; Wasukira et al. 2014). Nevertheless, the potential impact of common corn production practices in the United States on $X$. vasicola pv. vasculorum survival and subsequent bacterial leaf streak development is currently unknown. Research on agronomic practices that may contribute to disease development or its management is needed to focus future research directions and make management recommendations to producers. To address this need, a survey of agronomic practices used in corn fields with and without bacterial leaf streak symptoms was conducted during the 2016 and 2017 corn growing seasons. The objective of this survey was to use information collected from producers to gain a better understanding of which agronomic factors may be associated with the presence of $X$. vasicola pv. vasculorum in corn samples and subsequent bacterial leaf streak development. Portions of these results were presented previously in thesis and abstract formats (Hartman 2018; Hartman et al. 2017a, b, 2018b).

\section{MATERIALS AND METHODS}

Survey development and distribution. A survey instrument was developed to gain a better understanding of which agronomic practices and environmental factors commonly occurred in fields showing symptoms of versus being asymptomatic for infection by $X$. vasicola pv. vasculorum. Survey questions were generated based on those of a similar survey to gather information about the impacts of corn agronomic production practices on Goss's bacterial wilt and leaf blight (Langemeier et al. 2017) and research conducted on other xanthomonads. The bacterial leaf streak survey included questions about crop rotation and cover crops (O'Garro and Paulraj 1997), tillage and residue cover (Gent et al. 2005), soil type (Schaad and White 1974), irrigation (Schwartz et al. 2003; Gent et al. 2005), crop 
growth stages and symptom distribution, environmental stressors, and agricultural chemical use (Langemeier et al. 2017). Additionally, the survey included questions about proximity of symptomatic corn to other plants, such as weeds and those found in Conservation Reserve Program (CRP) acres (Gent et al. 2005), which are areas where prairie grasses are grown instead of crops. Prior to distribution, the Institutional Review Board at the University of Nebraska-Lincoln determined that this survey was exempt from review.

Survey packets were distributed in sealable clasp envelopes to producers, University of Nebraska-Lincoln Extension personnel, crop consultants, and agribusiness professionals during the 2016 and 2017 corn growing seasons. Packets included a copy of the survey (Supplementary Material), a letter detailing the purpose of the survey, and a 3.8-liter sealable zipper storage bag for leaf sample submission. Envelopes were addressed and postage paid. The primary focus of the survey was on corn fields in Nebraska, but some respondents submitted samples representing fields in other states. Survey respondents were most likely to attend corn disease update meetings or submit samples for testing if they were already aware of the disease or other unidentified issues in their fields and sought a diagnosis. This method knowingly led to sampling bias, but this was deemed acceptable to rapidly determine the distribution of the pathogen and obtain a geographically diverse collection of $X$. vasicola pv. vasculorum isolates. Respondents were asked to submit a symptomatic corn leaf sample for pathogen isolation and confirmation, along with the completed survey. X. vasicola $\mathrm{pv}$. vasculorum testing and diagnoses were provided at no charge as an incentive to encourage respondents to submit symptomatic samples.

Testing for $X$. vasicola pv. vasculorum. Sample processing began within $24 \mathrm{~h}$ of receiving samples. The presence of a bacterial pathogen was confirmed by microscopic observation of bacterial streaming from lesions on corn leaf samples submitted as part of the survey. A section of leaf tissue $\left(1 \times 1 \mathrm{~cm}^{2}\right)$ was excised out of lesions with a flame-sterilized razor blade and placed in sterile water on a microscope slide. A cover slip was placed over the excised leaf tissue and observed at $200 \times$ with a compound microscope. If bacterial streaming was observed from the lesion, a separate section $\left(3 \times 3 \mathrm{~cm}^{2}\right)$ of the symptomatic leaf tissue was excised with flamesterilized scissors and placed in a 50:50 mixture of 10\% sodium hypochlorite and $70 \%$ ethanol for $30 \mathrm{~s}$ (Schulz et al. 1993). The excised tissue was rinsed three separate times for $30 \mathrm{~s}$ in sterile water and transferred to a $0.5-\mathrm{ml}$ microcentrifuge tube containing $0.2 \mathrm{ml}$ of sterile water. The leaf tissue was cut five times with flame sterilized scissors to allow more of the bacteria to stream out of the tissue and into the water. One hour after cutting, a sterile loop was used to streak the suspension onto a nutrient broth yeast extract (Vidaver 1967) agar plate (Lang et al. 2017). Plates were incubated at $27^{\circ} \mathrm{C}$, and monitored for up to 5 days for suspect colony growth (Korus et al. 2017). Single yellow, mucoid colonies, the typical morphology of $X$. vasicola pv. vasculorum, were picked from the plate with sterile toothpicks and placed in $100 \mu$ l of autoclaved, DNase- and protease-free water previously filtered through a $0.2-$ $\mu \mathrm{m}$ filter (Fisher Bioreagents, Waltham, MA). The suspended bacterial colonies were used as the templates in the X. vasicola $\mathrm{pv}$. vasculorum-specific polymerase chain reaction (PCR) assay developed by Lang et al. (2017), with primers 5' -CAAGCAGAGCATGGCAAAC-3' and 5'-CACGTAGAACCGGTCTTTGG-3' (Integrated DNA Technologies, Coralville, IA). However, $12.5 \mu \mathrm{l}$ of premixed DreamTaq $2 \times$ PCR Master Mix (Thermo Fisher Scientific Waltham, MA) was used instead of the master mix used by Lang et al. (2017).

Statistical analyses. All analyses were conducted in $\mathrm{R}$ version 3.4.0. Survey questions answered by more than $50 \%$ of respondents were examined with classification and regression tree (CART) and random forest (Breiman 2001) analyses (Langemeier et al. 2017). These variables included irrigation type, planting date, crop rotation, tillage type, growth stage, CRP acres adjacent to the field, planting population, the use of cover crops, presence of broadleaf weeds including kochia (Bassia scoparia) and marestail (Conyza canadensis), and presence of grassy weed genera including foxtail (Setaria spp.), sandbur (Cenchrus spp.), and crabgrass (Digitaria spp.). CART was conducted with the recursive partitioning and regression trees (rpart) package version 4.1-11 to generate a classification tree (Lewis 2000) based on agronomic factors identified by survey respondents and the presence of $X$. vasicola pv. vasculorum in the corresponding sample. The tree was crossvalidated with the plotcp function, and a tree size that minimized the cross-validated error was selected. The prune function was used to prune the tree to this size. The algorithm used in the rpart package generated the classification tree by placing the agronomic factors with the most homogeneous $X$. vasicola pv. vasculorum test results at the top of the tree, with decreasing homogeneity as factors were placed lower in the tree. The tree was used to identify which agronomic factors were associated with samples testing positive for $X$. vasicola pv. vasculorum based on the entire dataset.

The random forest package version 4.6-12 was used to examine the same 14 variables examined in the CART analysis. This analysis was selected because it is less prone to overfitting to a specific dataset than CART. Random forest generated 100 decision trees from the 216 samples of the whole dataset, which were randomly chosen with replacement. All 14 predictors were considered at each partition in individual trees within the random forest, and one predictor was selected. The number of decision trees generated was based on the out-of-bag error rate, which was optimized at $17.9 \%$ when 100 decision trees were used. The agronomic factors were ranked in order of importance with the mean decrease Gini value, which measured the decrease in heterogeneity of sample results corresponding to an agronomic factor. A high decrease Gini value for a factor indicated that the $X$. vasicola pv. vasculorum test results (positive or negative PCR) were more homogeneous, and therefore better predictors of samples testing positive for $X$. vasicola $\mathrm{pv}$. vasculorum. Missing data were imputed with the na.roughfix function (Ishioka 2013), which imputed the median value in the dataset for a missing data point. No more than $50 \%$ of data were missing for each imputed value.

For variables with a response rate of less than $50 \%$ in the survey, a contingency table was created. A $\chi^{2}$ test of independence was used to determine whether a statistically significant relationship existed between agronomic factors and leaf samples testing positive for $X$. vasicola $\mathrm{pv}$. vasculorum $(\alpha=0.05)$. Only variables including at least 10 survey responses from each mutually exclusive outcome in the contingency table were examined with the $\chi^{2}$ analysis. Some factors could not be analyzed with CART, random forest, or the $\chi^{2}$ analyses due to low response rates.

On the survey, planting population and planting date were examined via open-ended questions, so responses were grouped for analysis. These groups were created based on those used in the Goss's bacterial wilt and leaf blight survey by Langemeier et al.

TABLE 1. Grouped responses to questions about corn seeding rates and planting dates in the 2016 and 2017 bacterial leaf streak survey ${ }^{a}$

\begin{tabular}{lcl}
\hline Group & Seeding rate (seeds/ha) & \multicolumn{1}{c}{ Planting date } \\
\hline Group 1 & $<54,999$ & On/before 21 April \\
Group 2 & $55,000-55,999$ & 22 April-1 May \\
Group 3 & $60,000-64,999$ & 2 May-12 May \\
Group 4 & $65,000-69,999$ & 13 May-23 May \\
Group 5 & $70,000-74,999$ & After 24 May \\
Group 6 & $75,000-79,999$ & - \\
Group 7 & $80,000-84,999$ & - \\
Group 8 & $85,000-89,999$ & - \\
Group 9 & $90,000-94,999$ & - \\
Group 10 & $95,000-100,000$ & -
\end{tabular}

a Groups were defined similar to those used by Langemeier et al. (2017). 
(2017). Planting populations for both growing seasons ranged from 32,123 to 93,900 seeds/ha and were divided into 10 groups (Table 1). Planting dates ranged from 4 April to 5 June for both growing seasons and were grouped into five groups for analysis (Table 1) (Langemeier et al. 2017).

\section{RESULTS}

Throughout the 2016 and 2017 corn growing seasons, 325 surveys were returned, at least partially completed, representing $16.3 \%$ of surveys distributed (Table 2). Each survey also included corn leaf samples from six states with most $(79.1 \%)$ from Nebraska. Of the 325 corn samples that were received, $80.8 \%$ tested positive and $19.1 \%$ tested negative for the presence of $X$. vasicola pv. vasculorum; $93.8 \%$ of samples were from dent corn, $5.1 \%$ from popcorn, and $0.9 \%$ from sweet corn.

Relationship between agronomic factors and samples testing positive for $X$. vasicola pv. vasculorum. Based on their inclusion in the classification tree after pruning, five of the 14 variables examined by the CART analysis were informative enough to be included in the tree: irrigation type, crop growth (or reproductive) stage, crop rotation, tillage type, and planting date.

TABLE 2. Number of corn samples received and testing positive for Xanthomonas vasicola pv. vasculorum by state in the 2016 and 2017 bacterial leaf streak survey ${ }^{\mathrm{a}}$

\begin{tabular}{lcrccccc}
\hline Number of leaf samples & CO & IA & KS & MO & NE & SD & $n$ \\
\hline Samples received & 9 & 11 & 20 & 2 & 280 & 3 & 325 \\
Samples testing positive $^{\mathrm{b}}$ & 7 & 8 & 16 & 0 & 229 & 2 & 262 \\
\hline
\end{tabular}

${ }^{a} \mathrm{CO}=$ Colorado, $\mathrm{IA}=$ Iowa, $\mathrm{KS}=$ Kansas, $\mathrm{MO}=$ Missouri, $\mathrm{NE}=$ Nebraska, $\mathrm{SD}=$ South Dakota, and $n=$ total.

b Samples were tested with Xanthomonas vasicola pv. vasculorum-specific polymerase chain reaction assay (Lang et al. 2017).
The CART analysis indicated that irrigation types center pivot, lateral, gravity, and subsurface were most strongly associated with samples testing positive for $X$. vasicola pv. vasculorum. Of the samples submitted, $86.4 \%$ were from irrigated fields and tested positive for $X$. vasicola pv. vasculorum, and $13.5 \%$ tested negative (Fig. 1). In non-irrigated fields, $42.0 \%$ of samples tested positive for $X$. vasicola pv. vasculorum, while $58.0 \%$ tested negative.

Growth stage when samples were collected was also an important predictor of samples testing positive for X. vasicola pv. vasculorum. When samples were obtained from irrigated fields, $90.3 \%$ of samples were from plants in the V7-R3 (vegetative to reproductive) stages tested positive for $X$. vasicola pv. vasculorum, and $9.6 \%$ tested negative. When plants in irrigated fields were not within this range of growth stages, $71.4 \%$ of samples tested positive for $X$. vasicola pv. vasculorum, while $28.5 \%$ tested negative.

Crop rotation was an important factor in non-irrigated fields, where $87.5 \%$ of samples from non-irrigated fields in a continuous corn, corn-corn-soybean, or corn-grain sorghum rotations tested positive for $X$. vasicola pv. vasculorum, and $12.5 \%$ tested negative. One-third of samples from non-irrigated fields in a corn-soybean, corn-soybean-wheat-soybean, or wheat-corn-fallow rotation tested positive for $X$. vasicola pv. vasculorum, while $66.7 \%$ of samples from these fields tested negative. In fields planted after 2 May, $87.5 \%$ of samples from irrigated fields with plants in the VE-V6 or $\mathrm{R} 4$ and later stages tested positive for $X$. vasicola pv. vasculorum, and $12.5 \%$ of samples from these fields tested negative. If fields under the same conditions were planted before 2 May, $50 \%$ of samples tested positive, and 50\% tested negative. In non-irrigated fields with a corn-soybean, corn-soybean-wheat-soybean, or wheat-corn-fallow rotation, tillage was an important predictor of disease. In these fields, if growers practiced minimum tillage, notill, or strip till, then $24.2 \%$ of samples tested positive, while $75.7 \%$ tested negative. If growers used conventional tillage in these same fields, $66.7 \%$ of samples tested positive and $33.3 \%$ of samples tested negative.

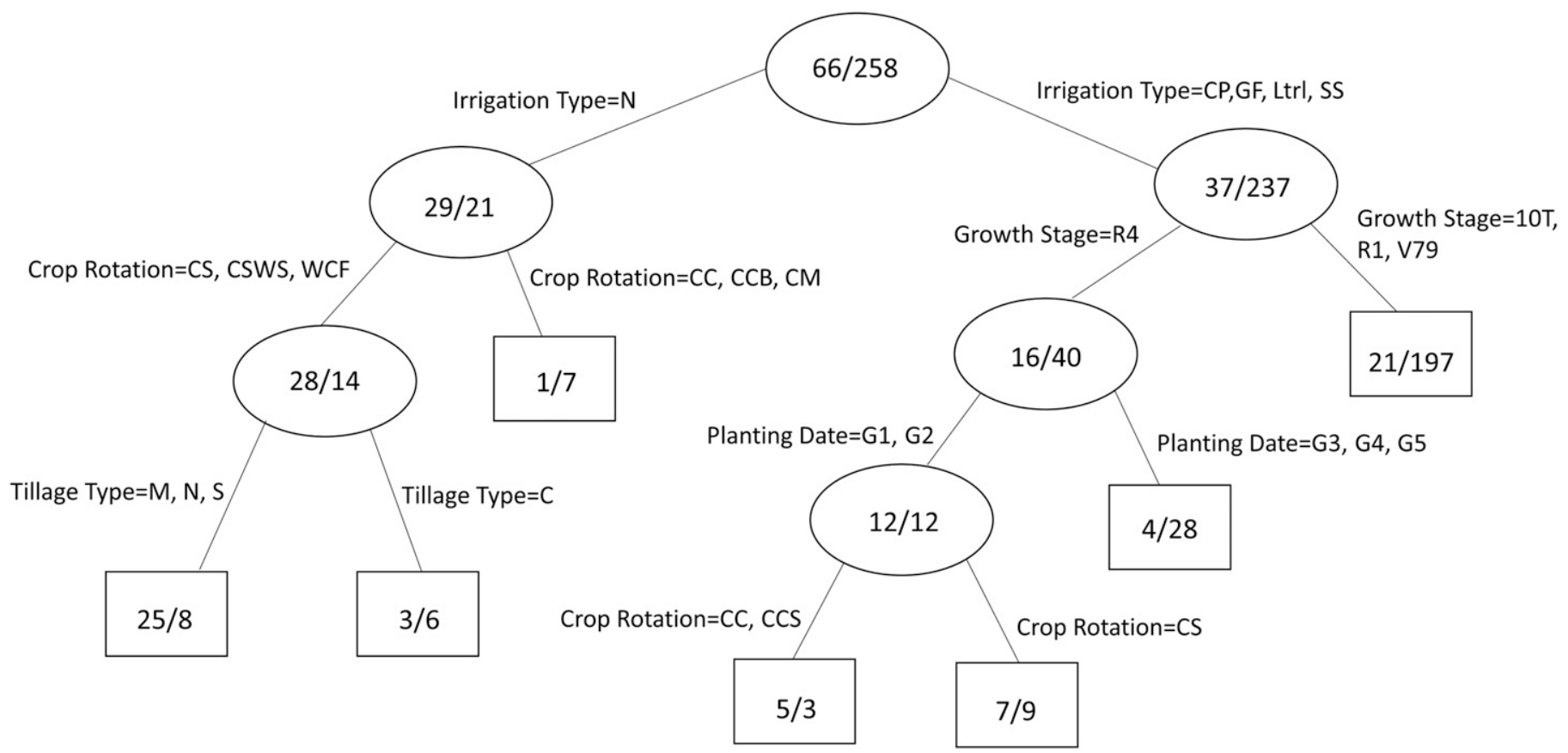

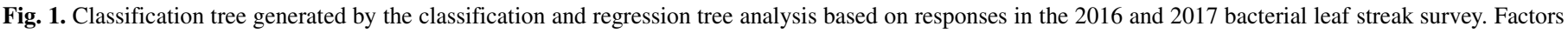

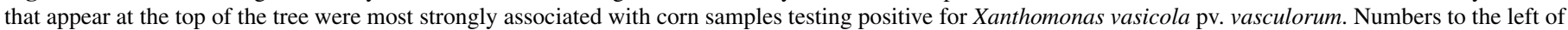

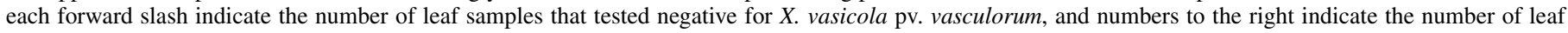

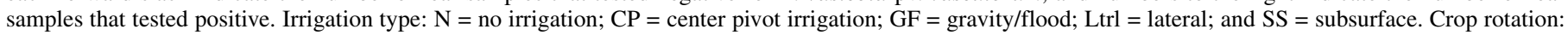

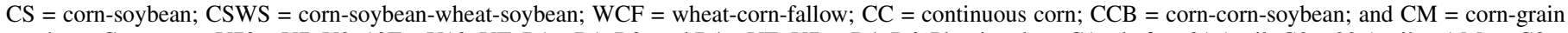

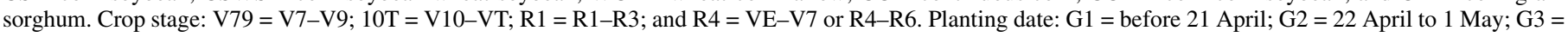

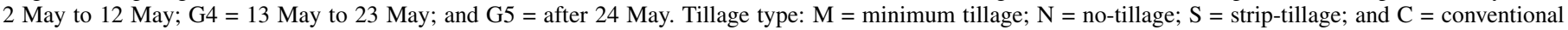
tillage. 
Variables determined to be the most important predictors of samples testing positive for $X$. vasicola pv. vasculorum during the 2016 and 2017 corn growing seasons, according to the mean decrease Gini values generated by random forest analysis included irrigation type, planting date, crop rotation, tillage type, and growth stage (Fig. 2). Both CART and random forest analysis recognized the same five variables as important factors predicting whether or not a sample tested positive for X. vasicola pv. vasculorum. However, with the exception of irrigation type being identified as

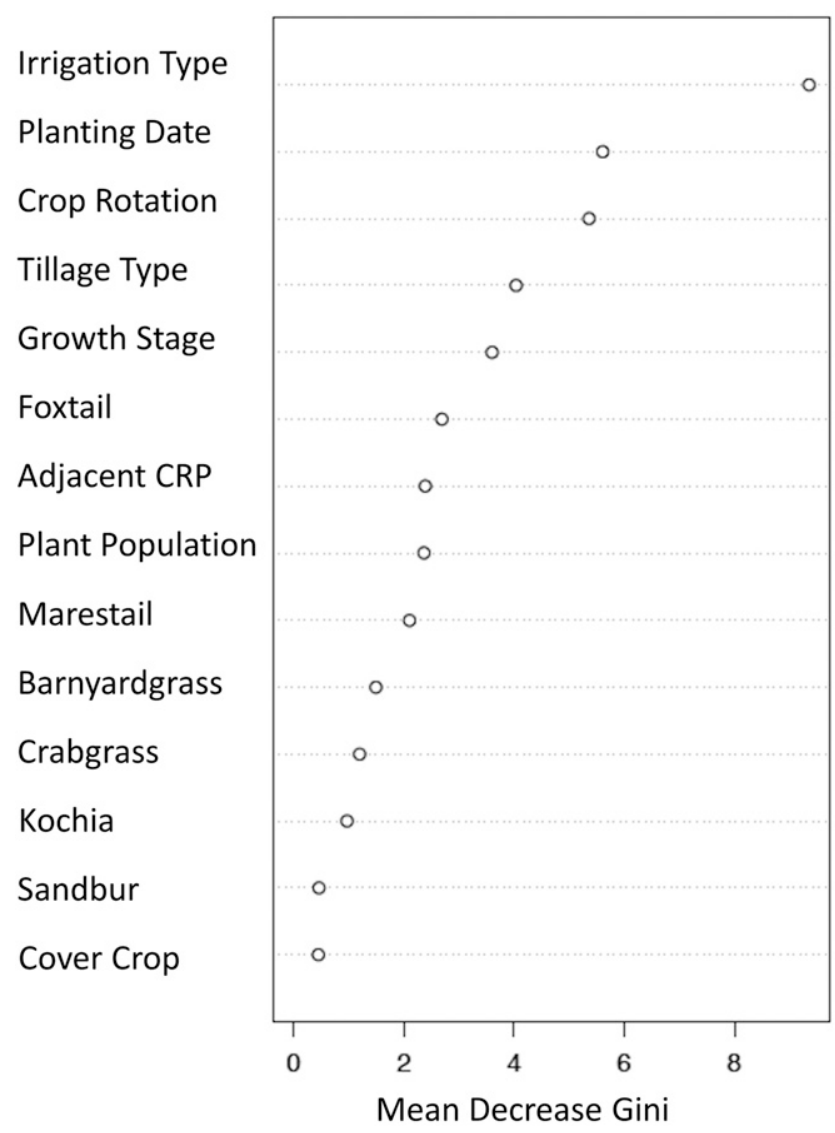

Fig. 2. Ranking of variable importance by the random forest analysis based on responses in the 2016 and 2017 bacterial leaf streak survey. Agronomic and environmental factors with higher decrease Gini values were more strongly associated with corn leaf samples testing positive for Xanthomonas vasicola pv. vasculorum.

TABLE 3. $\chi^{2}$ analysis of correlations between fertilizer application and corn sample test results for Xanthomonas vasicola pv. vasculorum in the 2016 and 2017 bacterial leaf streak survey

\begin{tabular}{|c|c|c|c|c|}
\hline \multirow[b]{2}{*}{ Fertilizer } & \multirow[b]{2}{*}{ Applied } & \multicolumn{2}{|c|}{$\begin{array}{l}X . \text { vasicola } \mathrm{pv} . \\
\text { vasculorum test } \\
\text { result }(\%)\end{array}$} & \multirow[b]{2}{*}{$P$ value } \\
\hline & & + & - & \\
\hline \multirow[t]{2}{*}{ At plant nitrogen } & Yes & 51.3 & 6.2 & \multirow[t]{2}{*}{0.0016} \\
\hline & $\begin{array}{c}\text { No } \\
n=160\end{array}$ & 28.8 & 13.8 & \\
\hline \multirow[t]{2}{*}{ Preplant potassium } & Yes & 34.2 & 7.7 & \multirow[t]{2}{*}{0.1000} \\
\hline & $\begin{array}{c}\text { No } \\
n=155\end{array}$ & 47.1 & 11.0 & \\
\hline \multirow[t]{2}{*}{ At plant potassium } & Yes & 27.9 & 3.2 & \multirow[t]{2}{*}{0.1153} \\
\hline & $\begin{array}{c}\text { No } \\
n=154\end{array}$ & 53.2 & 16.2 & \\
\hline \multirow[t]{2}{*}{ Preplant phosphorus } & Yes & 38.8 & 10.8 & \multirow[t]{2}{*}{0.8747} \\
\hline & $\begin{array}{c}\text { No } \\
n=157\end{array}$ & 40.1 & 10.2 & \\
\hline
\end{tabular}

the most important in both analyses, the factors were otherwise not ranked in the same order.

The $\chi^{2}$ analysis $(\alpha=0.05)$ indicated that a nitrogen application at planting may be correlated with a sample testing positive for $X$. vasicola pv. vasculorum (Table 3). However, potassium applied preplanting and at planting, and phosphorous applied preplanting did not affect the number of samples testing positive for $X$. vasicola pv. vasculorum. Herbicide applications containing the active ingredient glyphosate were related positively to a sample testing positive for $X$. vasicola pv. vasculorum. No other herbicide active ingredients affected sample test results, including acetochlor, Smetolachlor, or atrazine. Application of a fungicide was not related to a sample testing positive for $X$. vasicola pv. vasculorum (Table 4). There were insufficient survey responses to examine the effects of specific fungicide active ingredients. According to the $\chi^{2}$ analysis, neither a silt nor a clay soil type impacted whether a sample tested positive for $X$. vasicola pv. vasculorum (Table 5).

\section{DISCUSSION}

Surveys and leaf samples were voluntarily submitted and not randomly collected. Growers, consultants, and agribusiness professionals were asked to submit samples with bacterial leaf streak symptoms. Thus, the proportion of positive samples reported in this survey does not necessarily reflect the incidence of fields affected by $X$. vasicola pv. vasculorum. Additionally, some agronomic practices were better represented on the survey than others because of greater representation from some areas and states

TABLE 4. $\chi^{2}$ analysis of correlations between pesticide application and corn sample test results for Xanthomonas vasicola pv. vasculorum in the 2016 and 2017 bacterial leaf streak survey

\begin{tabular}{lcccc}
\hline & \multicolumn{4}{c}{$\begin{array}{c}\text { X. vasicola } \mathrm{pv} . \\
\text { vasculorum } \\
\text { test result }(\%)\end{array}$} \\
\cline { 2 - 4 } Pesticide active ingredient & Applied & + & - & $P$ value \\
\hline Acetochlor & Yes & 25.7 & 7.1 & 0.5458 \\
& No & 55.7 & 10.7 & \\
S-Metolachlor & $n=140$ & & & \\
& Yes & 27.9 & 4.3 & 0.2309 \\
Atrazine & No & 54.3 & 14.3 & \\
& $n=140$ & & & \\
Glyphosate & Yes & 42.1 & 9.3 & 0.9372 \\
& No & 40.0 & 9.3 & \\
Fungicide & $n=140$ & & & \\
& Yes & 55.7 & 7.1 & 0.0173 \\
& No & 25.7 & 10.7 & \\
& $n=140$ & & & \\
& Yes & 11.7 & 2.8 & 0.6649 \\
No & 71.0 & 13.8 & \\
\hline & $n=145$ & & & \\
\hline
\end{tabular}

${ }^{a}$ There were insufficient survey responses to examine the effects of specific fungicide active ingredients.

TABLE 5. $\chi^{2}$ analysis of correlations between soil types and sample test results for Xanthomonas vasicola pv. vasculorum in the 2016 and 2017 bacterial leaf streak survey

\begin{tabular}{lccrc}
\hline & & \multicolumn{2}{c}{$\begin{array}{c}X . \text { vasicola } \text { pv. } \\
\text { vasculorum } \text { test } \\
\text { result }(\%)\end{array}$} & \\
\cline { 3 - 4 } Soil type & Present & + & - & $P$ value \\
\hline Silt & Yes & 27.9 & 7.8 & 0.8267 \\
& No & 50.8 & 12.9 & \\
Clay & $n=279$ & & & \\
& Yes & 8.9 & 5.0 & 0.06669 \\
& No & 69.9 & 16.1 & \\
& $n=279$ & & & \\
\hline
\end{tabular}


where corn production practices differed locally or where the disease was more common. For example, fields with greater yield potential, such as irrigated fields, were more likely to be scouted and more likely to have samples collected than non-irrigated fields. These results are a reflection of what occurred in some fields during the 2016 and 2017 growing seasons, and other factors may influence disease development in other areas or time periods. It is important to also recognize that the responses to survey questions may have also been subjective and that they may have impacted the results of our analyses.

Slight discrepancies occurred between the results of the CART and random forest analyses. The differences in rankings of the importance of agronomic factors are likely due to the inherent differences in these two analyses. While the CART analysis builds a single tree based on the entire dataset, random forest uses sampling within the dataset to build several trees. The trees built by random forest are then used to generate a mean decrease Gini value for each factor, based on the decrease Gini values for that factor across all generated trees. Both CART and random forest are informative, especially when used together, because CART generates one tree based on the entire dataset and the tree may be overfit to that dataset. The issue of overfitting is mitigated by the random sampling used in the random forest analysis.

Results of both analyses indicated that irrigation, crop rotation, growth stage, tillage, and planting date were the most important predictors of samples testing positive for $X$. vasicola $\mathrm{pv}$. vasculorum, although not in the same order. These results are consistent with those from the Goss's bacterial wilt and blight survey conducted by Langemeier et al. (2017), which also showed that CART and random forest analyses identified the same five agronomic factors as the most important predictors of samples testing positive for the pathogen, although the order of their rankings varied, similar to these results.

Results of the CART analysis indicated that samples submitted for the survey from irrigated fields were more likely to test positive for X. vasicola pv. vasculorum; however, no specific type of irrigation was singled out as the most important predictor. Samples were more likely to test positive for $X$. vasicola pv. vasculorum when they originated from irrigated versus non-irrigated fields. Likewise, the random forest analysis indicated that the most important predictor for corn samples testing positive for $X$. vasicola pv. vasculorum was the use of irrigation (Fig. 2).

An increase in humidity can occur when moisture is introduced into fields via any type of irrigation (Boucher et al. 2004). According to results from greenhouse experiments by Tharnish et al. (2017), bacterial leaf streak symptom severity increased on plants inoculated with $X$. vasicola pv. vasculorum when they were maintained in $100 \%$ relative humidity for increasing periods of time compared with those maintained on the greenhouse bench at ambient relative humidity. High relative humidity can cause plants to open their stomata (Lange et al. 1971), and Korus et al. (2017) suggested that $X$. vasicola $\mathrm{pv}$. vasculorum may infect plants through natural openings. Therefore, it is possible that increased relative humidity due to irrigation may favor $X$. vasicola pv. vasculorum infection and subsequent bacterial leaf streak development. Additionally, high relative humidity increases the duration of leaf wetness, which is necessary for the epiphytic survival and reproduction of some bacteria prior to infection (Duthie 1997). $X$. axonopodis pv. allii, causal agent of bacterial leaf blight of onion, survives and can be disseminated in irrigation water (Gent et al. 2005). It is currently unknown whether $X$. vasicola pv. vasculorum is also capable of survival and dissemination in irrigation water; however, results from both CART and random forest analyses indicated irrigation as a factor for samples testing positive for $X$. vasicola pv. vasculorum.

Growth stage was also an important predictor of $X$. vasicola $\mathrm{pv}$. vasculorum detection in corn samples obtained from irrigated fields (Fig. 1). This may be due to the increased likelihood of irrigated fields to be monitored midseason for diseases and other problems, compared with non-irrigated fields, which are less likely to be scouted (T. Jackson-Ziems, personal communication). This may explain why 197 samples with X. vasicola pv. vasculorum were from irrigated fields collected at V10-R3 growth stages. Alternatively, infection may have occurred earlier in the growing season and symptom severity may have progressed to a noticeable level during the V10-R3 growth stages. This is possible considering that Tharnish et al. (2017) demonstrated symptom development as early as VE (emergence) in the greenhouse.

Planting date was also identified as an important predictor for samples testing positive for $X$. vasicola pv. vasculorum from irrigated fields where plants were collected early (VE-V6) versus during later (R4 and later) growth stages (Fig. 1). According to results from the CART analysis, a planting date on or after 2 May was an important predictor of a sample testing positive from these fields. Paul and Munkvold (2004) demonstrated with a similar CART model that gray leaf spot development on corn was also influenced by a later planting date. The planting date could impact the growth stage of the plants during specific meteorological events, such as temperature extremes and precipitation events. The relationship between planting date and weather conditions, which can also influence factors such as soil temperature and moisture, has been demonstrated to be important in other pathosystems, such as sudden death syndrome in soybean (Hershman et al. 1990; Wrather et al. 1995) as well as Pythium seedling blight of corn (Chen 2016).

Results from the CART analysis showed that crop rotation sequence was associated with samples testing positive for $X$. vasicola pv. vasculorum in non-irrigated fields (Fig. 1). Samples from non-irrigated fields with continuous corn, corn-corn-soybean, or a corn-grain sorghum rotation sequences were more likely to test positive than samples collected from non-irrigated fields that were rotated away from corn after one season. Because $X$. vasicola $\mathrm{pv}$. vasculorum overwinters in infested crop residue (Ortiz-Castro et al. 2018), multiple seasons of corn may lead to a buildup of inoculum, making disease development more likely where corn is grown more frequently. Likewise, according to North (1935), gumming disease in sugarcane also caused by $X$. vasicola pv. vasculorum, was more difficult to control in New South Wales than in the tropics due to the common use of a 2-year sugarcane crop rotation. A 2-year corn rotation, such as the corn-corn-soybean rotation identified in the CART tree as a predictor of disease, may have a similar effect on bacterial leaf streak development in corn. A corn-grain sorghum rotation was also a significant predictor of a sample testing positive for $X$. vasicola pv. vasculorum, and was grouped with the continuous corn and corn-corn-soybean rotations in the CART analysis (Fig. 1). This is intriguing, as Lang et al. (2017) and Hartman et al. (2020) demonstrated that in the greenhouse $X$. vasicola pv. vasculorum was capable of infecting and causing disease in sorghum; however, bacterial leaf streak symptoms have not been observed in sorghum fields near diseased corn fields in Nebraska or Kansas (T. Jackson-Ziems and D. Jardine, personal communications).

Interestingly, in non-irrigated fields rotated away from corn after one season, where minimum tillage, no-tillage, or strip tillage was used, only $24 \%$ of samples tested positive for $X$. vasicola pv. vasculorum (Fig. 1). In contrast, $67 \%$ of samples obtained from fields where conventional tillage was used tested positive for the presence of $X$. vasicola pv. vasculorum. This seems counterintuitive if $X$. vasicola pv. vasculorum is capable of overwintering in infested crop residue. Conventional tillage is expected to be more effective than minimal tillage methods (such as no tillage, strip tillage, and ridge tillage) at promoting degradation of infested crop residue that can serve as an inoculum source (Peters et al. 2003). However, the results obtained from the survey may be biased due to small sample sizes at this node. Only nine respondents in this group reported using conventional tillage, whereas 33 respondents reported using a type of minimum tillage. 
Foxtail (Setaria spp.) was the only alternative host of $X$. vasicola pv. vasculorum (Hartman et al. 2018a, 2020) that was identified as a predictor for a corn sample testing positive for $X$. vasicola $\mathrm{pv}$. vasculorum in results from the random forest analysis, and its presence in a field was not a strong predictor (Fig. 2). However, only weeds that were identified as problematic by more than $50 \%$ of survey respondents were examined with the random forest analysis. Some respondents reported other alternative hosts of $X$. vasicola $\mathrm{pv}$. vasculorum as problematic, including johnsongrass (Sorghum halepense) and shattercane (Sorghum bicolor) (Hartman et al. 2018a, 2020); however there were not enough reports for these weeds to be examined with the random forest or $\chi^{2}$ analyses. Additionally, despite seven prairie grasses being identified as alternative hosts for $X$. vasicola pv. vasculorum (Hartman et al. 2018a, 2020), the proximity of CRP acres to the corn field was not a strong predictor of a corn sample testing positive for $X$. vasicola $\mathrm{pv}$. vasculorum. It is possible that because $X$. vasicola pv. vasculorum infects these alternative host plants at such a low incidence in the field under natural noninoculated conditions that their presence does not increase the likelihood of disease development in corn (Hartman et al. 2018a, 2020).

Preplant nitrogen fertilizer application was a predictor of a corn sample testing positive for $X$. vasicola pv. vasculorum according to results from the $\chi^{2}$ analysis (Table 3 ). Results from research conducted by Gent and Schwartz (2005) showed that when high rates of nitrogen fertilizer were applied, symptom severity associated with $X$. axonopodis pv. allii infection of onion increased by up to $50 \%$ when environmental conditions were favorable for the pathogen. Elings et al. (1997) observed a similar effect when excessive nitrogen was applied to rice fields following infection with $X$. oryzae pv. oryzae. It is unknown whether respondents to this survey applied abnormally high rates of nitrogen in their preplant fertilizer applications. The majority of survey responses were collected during the 2016 growing season when the environment was seemingly more favorable for infection by $X$. vasicola $\mathrm{pv}$. vasculorum, based on the increased incidence of bacterial leaf streak that year compared with 2017. A survey conducted during a less environmentally favorable year for disease development may not produce the same results. Effects of high nitrogen application rates have not been investigated on $X$. vasicola pv. vasculorum in corn in the field, and further field experiments are needed to determine the effects of preplant nitrogen applications on bacterial leaf streak development.

Application of herbicides containing glyphosate was identified as a predictor for samples testing positive for $X$. vasicola $\mathrm{pv}$. vasculorum (Table 4). Langemeier et al. (2017) reported similar results where glyphosate applications were implicated as possible factors for infection of corn by Clavibacter michiganensis subsp. nebraskensis causing Goss's bacterial wilt and leaf blight. Glyphosate can reportedly impact plant susceptibility to diseases such as sudden death syndrome and root rot of soybean (Keen et al. 1982), root rot of barley (Smiley et al. 1992), and take-all of wheat (Hornby et al. 1998) by affecting the plant immune system. Inducible defenses, such as the phenylpropanoid pathway (Dixon et al. 2002) and production of pathogenesis-related proteins (Hammond-Kosack and Jones 2000) rely on the shikimic pathway or its products. The mechanism of action of glyphosate is to block the shikimic pathway, which may inhibit proper function of the plant immune system (Johal and Huber 2009). Notably, only increased susceptibility to soilborne, root-infecting fungal and oomycete pathogens have been reported previously. The effect of glyphosate on Goss's bacterial wilt and blight and bacterial leaf streak development in corn, both caused by bacterial pathogens, may be different. Field trials conducted by Schlund (2015) investigated the relationship between Clavibacter michiganensis subsp. nebraskensis and other agricultural chemicals, including glyphosate, and found no relationship between herbicide applications and subsequent severity of Goss's bacterial wilt and blight. As
Langemeier et al. (2017) noted, reduced tillage practices are common when glyphosate is used for weed control. Reduced tillage leaves pathogen-infested crop residue on the soil surface that can act as a source of inoculum for disease development. This scenario may be the more important factor impacting the incidence of pathogens in corn fields where glyphosate is used. Additionally, both glyphosate and nitrogen are typically applied to intensely managed corn fields which are also more likely to be scouted for diseases. Further research is needed to determine whether disease development is truly affected by these factors.

This survey demonstrated that irrigation, planting date, crop rotation, and tillage are all agronomic practices that may affect bacterial leaf streak development in corn. These results indicate that certain agronomic practices used for commercial corn production in the represented states may have contributed to infection by $X$. vasicola pv. vasculorum. Based on the survey results, further research on bacterial leaf streak management should focus on planting dates, irrigation, and crop rotation as potential management strategies for bacterial leaf streak. Further research is also needed to understand how environmental factors and residue cover influences disease development, as well as how irrigation impacts pathogen spread and infection. Management recommendations should not be made based on these results until they are verified in field and greenhouse studies. These results can be used to better focus future research efforts toward more effective bacterial leaf streak management.

\section{ACKNOWLEDGMENTS}

We thank the Nebraska Corn Board for supporting this work; Reka Howard for assistance with the random forest analyses; Justin Weissling, Neal Colaric, and Jen Anderson for technical assistance; and all growers, industry personnel, and extension personnel who collected samples and submitted surveys.

\section{LITERATURE CITED}

Boucher, O., Myhre, G., and Myhre, A. 2004. Direct human influence of irrigation on atmospheric water vapour and climate. Clim. Dyn. 22: 597-603.

Bowman, N. D., and Bissonnette, S. 2016. New bacterial leaf disease "bacterial leaf streak" identified in one northern Illinois county. The Bulletin. University of Illinois Extension

Breiman, L. 2001. Random forests. Mach. Learn. J. 45:5-32.

Chen, W. 2016. Pythium root rot (and feeder root necrosis). Pages 23-25 in: Compendium of Corn Diseases. G. P. Munkvold and D. G. White, eds. American Phytopathological Society, St. Paul, MN.

Dixon, R. A., Achnine, L., Kota, P., Liu, C. J., Reddy, M. S., and Wang, L. 2002. The phenylpropanoid pathway and plant defense-a genomics perspective. Mol. Plant Pathol. 3:371-390.

Duthie, J. A. 1997. Models of the response of foliar parasites to the combined effects of temperature and duration of wetness. Phytopathology 87: 1088-1095.

Dyer, R. A. 1949. Botanical surveys and control of plant diseases. Farming in South Africa. Annu. Rep. Dep. Agric. S. Afr. 275:119-121.

Elings, A., Reddy, P. R., Marimuthu, T., Rossing, W. A. H., Jansen, M. J. W., and Teng, P. S. 1997. Rice bacterial leaf blight: Field experiments, systems analysis and damage coefficients. Field Crops Res. 51:113-131.

Gent, D. H., Lang, J. M., Bartolo, M. E., and Schwartz, H. F. 2005. Inoculum sources and survival of Xanthomonas axonopodis pv. allii in Colorado. Plant Dis. 89:507-514.

Gent, D. H., and Schwartz, H. F. 2005. Effect of nitrogen fertilization and seed contamination on epiphytic populations of Xanthomonas axonopodis pv. allii and development of Xanthomonas leaf blight of onion. Plant Health Prog. 6:12.

Hammond-Kosack, K., and Jones, J. D. G. 2000. Responses to plant pathogens. Pages 1102-1156 in: Biochemistry and Molecular Biology of Plants. B. B. Buchanan, W. Gruissem, and R. L. Jones, eds. American Society of Plant Physiology, Rockville.

Hartman, T., Harbour, J., Tharnish, B., Van Meter, J., Eskridge, K., and Jackson-Ziems, T. A. 2017b. Distribution of bacterial leaf streak of corn caused by Xanthomonas vasicola in Nebraska. (Abstr.) Phytopathology 107(suppl.):S5.171. 
Hartman, T., Harbour, J., Tharnish, B., Van Meter, J., and Jackson-Ziems, T. 2017a. Epidemiology and distribution of bacterial leaf streak of corn caused by Xanthomonas vasicola. (Abstr.) Phytopathology 107:S5.165.

Hartman, T., Tharnish, B., Harbour, J., and Jackson-Ziems, T. 2018a. Alternative hosts of Xanthomonas vasicola pv. vasculorum causing bacterial leaf streak of corn. (Abstr.) Phytopathology 108(suppl.):S2.28.

Hartman, T., Tharnish, B., Harbour, J., Van Meter, J., Eskridge, K, and Jackson-Ziems, T. A. 2018b. Distribution of bacterial leaf streak of corn caused by Xanthomonas vasicola pv. vasculorum in Nebraska and factors that influence its development. (Abstr.) Phytopathology 108(suppl.):S2.27.

Hartman, T., Tharnish, B., Harbour, J., Yuen, G. Y., and Jackson-Ziems, T. A. 2020. Alternative hosts in the families Poaceae and Cyperaceae for Xanthomonas vasicola pv. vasculorum, causal agent of bacterial leaf streak of corn. Phytopathology 110:1147-1152.

Hartman, T. M. 2018. Investigation of alternative hosts and agronomic factors affecting Xanthomonas vasicola pv. vasculorum, causal agent of bacterial leaf streak of corn. M.S. Thesis. University of Nebraska-Lincoln.

Hershman, D. E., Hendrix, J. W., Stuckey, R. E., Bachi, P. R., and Henson, G. 1990. Influence of planting date and cultivar on soybean sudden death syndrome in Kentucky. Plant Dis. 74:761-766.

Hornby, D., Bateman, G. L., Gutteridge, R. J., Lucas, P., Osbourn, A. E., Ward, E., and Yarham, D. J. 1998. Take-All Disease of Cereals: A Regional Perspective. CAB International, Wallingford, U.K.

Ishioka, T. 2013. Imputation of missing values for unsupervised data using the proximity in random forests. Pages 30-36 in: The fifth international conference on mobile, hybrid, and on-line learning. International Academy, Research, and Industry Association, Wilmington, DE.

Johal, G. S., and Huber, D. M. 2009. Glyphosate effects on diseases of plants. Eur. J. Agron. 31:144-152.

Karamura, G., Smith, J., Studholme, D., Kubiriba, J., and Karamura, E. 2015. Comparative pathogenicity studies of the Xanthomonas vasicola species on maize, sugarcane and banana. Afr. J. Plant Sci. 9:385-400.

Keen, N. T., Holliday, M. J., and Yoshikawa, M. 1982. Effects of glyphosate on glyceollin production and the expression of resistance to Phytophthora megasperma f. sp. glycinea in soybean. Phytopathology 72:1467-1470.

Korus, K., Lang, J. M., Adesemoye, A. O., Block, C. C., Pal, N., Leach, J. E., and Jackson-Ziems, T. A. 2017. First report of Xanthomonas vasicola causing bacterial leaf streak on corn in the United States. Plant Dis. 101:1030.

Lang, J. M., DuCharme, E., Ibarra Caballero, J., Luna, E., Hartman, T., Ortiz-Castro, M., Korus, K., Rascoe, J., Jackson-Ziems, T. A., Broders, K., and Leach, J. E. 2017. Detection and characterization of Xanthomonas vasicola pv. vasculorum (Cobb 1894) comb. nov. causing bacterial leaf streak of corn in the United States. Phytopathology 107:1312-1321.

Lange, O. L., Lösch, R., Schulze, E. D., and Kappen, L. 1971. Responses of stomata to changes in humidity. Planta 100:76-86.

Langemeier, C. B., Robertson, A. E., Wang, D., Jackson-Ziems, T. A., and Kruger, G. R. 2017. Factors affecting the development and severity of Goss's bacterial wilt and blight of corn, caused by Clavibacter michiganensis subsp. nebraskensis. Plant Dis. 101:54-61.

Leite, R. P., Custódio, A. A. P., Madalosso, T., Rodrigues Robaina, R. R., Duin, I. M., and Sugahara, V. H. 2018. First report of the occurrence of bacterial leaf streak of corn caused by Xanthomonas vasicola pv. vasculorum in Brazil. Plant Dis. 103:145.

Lewis, R. J. 2000. An introduction to classification and regression tree (CART) analysis. Presented at the 2000 Annual Meeting of the Society for
Academic Emergency Medicine in San Francisco, CA. http://citeseerx.ist. psu.edu/viewdoc/download?doi=10.1.1.95.4103\&rep=rep1\&type=pdf

North, D. S. 1935. The gumming disease of sugarcane, its dissemination and control. Agric. Rep. Colon. Sug. Refg Co. 10(tech):149.

O'Garro, L. W., and Paulraj, L. P. 1997. Onion leaf blight caused by Xanthomonas campestris: Alternative hosts and resistant onion genotypes. Plant Dis. 81:978-982.

Ortiz-Castro, M., Jacobs, J. M., Plazas, M. C., Lang, J. M., Jackson-Ziems, T. A., Leach, J. E., Robertson, A. E., and Broders, K. D. 2018. Understanding the mechanisms of infection and survival of the maize pathogen Xanthomonas vasicola pv. vasculorum. (Abstr.) Phytopathology 108(suppl.):S1.204

Paul, P. A., and Munkvold, G. P. 2004. A model-based approach to preplanting risk assessment for gray leaf spot of maize. Phytopathology 94 : 1350-1357.

Peters, R. D., Sturz, A. V., Carter, M. R., and Sanderson, J. B. 2003. Developing disease-suppressive soils through crop rotation and tillage management practices. Soil Tillage Res. 72:181-192.

Plazas, M. C., De Rossi, R. L., Brücher, E., Guerra, F. A., Vilaró, M., Guerra, G. D., Wu, G., Ortiz-Castro, M. C., and Broders, K. 2018. First report of Xanthomonas vasicola pv. vasculorum causing bacteria leaf streak of maize (Zea mays) in Argentina. Plant Dis. 102:1026.

Ricaud, C., and Autrey, L. J. C. 1989. Gumming disease. Pages 21-38 in: Diseases of Sugarcane. Elsevier, Amsterdam.

Schaad, N. W., and White, W. C. 1974. Survival of Xanthomonas campestris in soil. Phytopathology 64:1518-1520.

Schlund, S. A. 2015. Goss's bacterial wilt development and Clavibacter michiganensis subsp. nebraskensis interactions with spray adjuvants. M.S. Thesis, University of Nebraska-Lincoln.

Schulz, B., Wanke, U., Draeger, S., and Aust, H. J. 1993. Endophytes from herbaceous plants and shrubs: Effectiveness of surface sterilization methods. Mycol. Res. 97:1447-1450.

Schwartz, H. F., Otto, K. L., and Gent, D. H. 2003. Relation of temperature and rainfall to development of Xanthomonas and Pantoea leaf blights of onion in Colorado. Plant Dis. 87:11-14.

Smiley, R. W., Ogg, A. G., and Cook, R. J. 1992. Influence of glyphosate on Rhizoctonia root rot, growth, and yield of barley. Plant Dis. 76:937-942.

Tharnish, B., Hartman, T., Harbour, J., and Jackson-Ziems, T. A. 2017. Effects of high relative humidity on severity of bacterial leaf streak of corn caused by Xanthomonas vasicola in the greenhouse. (Abstr.) Phytopathology 107(suppl.):S5.171

USDA-NASS. 2016. Crop Production Summary. U.S. Department of Agriculture National Agriculture Statistics Service. https://www.nass.usda.gov

Vidaver, A. K. 1967. Synthetic and complex media for rapid detection of fluorescence of phytopathogenic pseudomonads: Effect of the carbon source. Appl. Microbiol. 15:1523-1524.

Wasukira, A., Coulter, M., Al-Sowayeh, N., Thwaites, R., Paszkiewicz, K., Kubiriba, J., Smith, J., Grant, M., and Studholme, D. J. 2014. Genome sequencing of Xanthomonas vasicola pv. vasculorum reveals variation in plasmids and genes encoding lipopolysaccharide synthesis, type-IV pilus and type-III secretion effectors. Pathogens 3:211-237.

Wrather, J. A., Kendig, S. R., Anand, S. C., Niblack, T. L., and Smith, G. S. 1995. Effects of tillage, cultivar, and planting date on percentage of soybean leaves with symptoms of sudden death syndrome. Plant Dis. 79: 560-562. 